\title{
The Use of Kitchen Effluent as Alternative Nutrient Source for Bioremediation of Oil Based Drilling Muds
}

\section{1*UMANU GODDEY; ${ }^{2}$ NWACHUKWU SIMONCYRIL U}

\author{
${ }^{1}$ Department of Biological Sciences, Bells University of Technology, Km 8, Idiroko Road, Benja Village, P.M.B. 1015, Ota, Ogun State, \\ Nigeria. E-mail: goddeysu@yahoo.com, Phone: +2348035106978 \\ ${ }^{2}$ Department of Botany and Microbiology, Faculty of Science, University of Lagos, Akoka Yaba, Lagos, Nigeria.
}

\begin{abstract}
The recovery of oil based drilling muds was monitored for a period of 12 weeks upon inoculation with kitchen effluent. Oil based drilling muds inoculated with varying volumes $(200 \mathrm{ml}, 250 \mathrm{ml}$ and $300 \mathrm{ml})$ of kitchen effluent constituted the experimental set-ups, while the control set-ups were made up of oil based drilling muds inoculated with varying volumes $(200 \mathrm{ml}, 250 \mathrm{ml}$ and $300 \mathrm{ml}$ respectively) of sterile distilled water. In the experimental set-ups which received additional hydrocarbon utilizers $\left(4.15 \times 10^{4} \pm 0.12 \mathrm{cfu} / \mathrm{ml}\right)$ as well as phosphate $(3.63 \mathrm{mg} / \mathrm{l})$, sulphate $(3.0 \mathrm{mg} / \mathrm{l})$ and nitrate $(15.60 \mathrm{mg} / \mathrm{l})$ present in the kitchen effluent, both dissolved oxygen (DO) and residual oil concentration (ROC) decrease rapidly while the increasing trends in biochemical oxygen demand (BOD) were much more pronounced over the period when compared with the control set-ups. However, analysis of data obtained from this study revealed that the differences between the mean residual oil concentration of the experimental set-ups and that of the control set-ups for $\mathrm{A}$ and $\mathrm{B}$ are insignificant while that of $\mathrm{C}$ differed significantly at $5 \%$ probability level indicating that the magnitude of loss in residual oil concentration increases as the volume of kitchen effluent inoculated increases. Therefore, it may be necessary to use kitchen effluent as alternative inoculum in bioremediation of oil contaminated drilling muds. @ JASEM
\end{abstract}

Decades of offshore and inland petroleum drilling and production operations have provide the much needed energy and chemical feedstock for the nation, but they also have made an impact on the environment in the area (Fang, 1990; Nwachukwu, 2000a; Nweke and Okpokwasili, 2003; Okolo et al., 2005). Various operations are needed to support the production of oil and gas. In these operations, a broad range of chemicals are used, and some of them have important environmental implications (Petrazzuolo et al., 1995; Fang, 1990).

An important aspect of the environmental impact of offshore drilling operations is the discharge of oil based drilling muds. Drilling muds are chemical mixtures used for rotary drilling in the extraction of oil and gas from the earth's crust (Okpokwasili and Nnubia, 1995). Essentially, a drilling mud is a suspension of solids (e.g. clays, barite, small cuttings, etc.) in liquids (i.e. water or oil) or in liquid emulsions, with chemical additives as required to modify its properties (Ifeadi et al., 1985). The chemical additives include bactericides, surface active agents, dispersants and viscosifiers (Okpokwasili and Nnubia, 1995). The general functions of drilling mud in the borehole include; lifting of formation cuttings to the surface, control of subsurface pressures, lubrication of drill stings and sides of the hole, bottom hole cleaning and cooling, provision of aid to formation evaluation, and maintenance of stability of uncased sections of the borehole (Ifeadi et al., 1985; Okpokwasili and Nnubia, 1995).
Diesel oils used in oil based drilling mud formulations were found to be toxic to a wide range of microorganisms due to high concentration of potentially toxic materials $(20-30 \% 2-, 3$ - and 4-ring aromatics) (Nweke and Okpokwasili, 2003). Consequently, highly refined low toxicity base oil that has low concentration of aromatic compounds (1-10\%) becomes the alternative (Candler et al., 1993). Nevertheless, the used drilling mud, additives and oil-laden drill cuttings still pose a serious threat to the biota of aquatic and terrestrial ecosystems (Nweke and Okpokwasili, 2003). The discharge of oil based drilling muds as well as the release of crude petroleum and petroleum products into human environments have resulted in many problems that are of much concern globally (Atlas, 1981; Nwachukwu, 2000b; Nweke and Okpokwasil, 2003). The long persistence of these pollutants in environments was attributed to low numbers of hydrocarbon utilizers and to the toxicity of crude oil on natural flora (Atlas, 1991; Nwachukwu, 2000b).

Investigations of biodegradation of cutting piles and the microbial population associated with drilling muds have been conducted (Nnubia and Okpokwasili, 1993; Benka-Coker and Olumagin, 1995; Nweke and Okpokwasili, 2003). Both bacteria and fungi have also been developed and used to enhance rehabilitation of environments polluted with crude petroleum and its products (Nwachukwu et al., 1999; Eriksson et al., 2000; Nwachukwu, 2000a; Sayler and Ripp, 2000, Mishra et al. 2001). Poultry manure has over time been used to improve soil fertility (Okolo et al., 2005). Its efficacy in promoting 
plant growth in crude oil polluted Nigerian soils, and the impact of its addition alone and in combination with surfactants or alternate carbon substrate to enhance crude oil degradation has also been reported (Amadi and Uebari, 1992; Ogboghodo et al., 2004; Okolo et al., 2005). Similarly, domestic effluent has over time been used to improve soil fertility (Bond, 1998; Barton et al., 2005). In this study, the impacts of addition of kitchen effluent to enhance rehabilitation of oil based drilling muds were investigated.

\section{MATERIALS AND METHODS}

Study Materials: The oil based drilling muds treated in this study was obtained from an oil field in Nigeria, while the kitchen effluent used for the treatment was obtained from restaurants drainage channel at the University of Lagos, Nigeria. The kitchen effluent sample collected was analysed microbiologically for the presence of hydrocarbon utilizers (HCU), and the total heterotrophic microorganisms (THM) present in the kitchen effluent was estimated. The sulphate, nitrate and phosphate contents as well as the biochemical oxygen demand (BOD) and dissolved oxygen (DO) of the kitchen effluent collected were determined.

Bioremediation Protocols: The oil based drilling muds was mixed thoroughly to homogenize it. Thereafter, $2.0 \mathrm{~kg}$ each of the homogenized drilling muds was weighed into six pans (internal dimensions, $40 \mathrm{~cm} \times 40 \mathrm{~cm} \times 7.5 \mathrm{~cm})$ and were labelled "experimental set-up A (ESUA), control setup A (CSUA), experimental set-up B (ESUB), control set-up B (CSUB), experimental set-up C (ESUC) and control set-up C (CSUC)". The experimental set-ups (ESUA, ESUB, and ESUC) were inoculated with $200 \mathrm{ml}, 250 \mathrm{ml}$ and $300 \mathrm{ml}$ kitchen effluent respectively (containing approximately $8.14 \times 10^{8}+0.06 \mathrm{cfu} / \mathrm{ml}$ total heterotrophic microorganisms (THM); $4.15 \times 10^{4} \pm$ $0.12 \mathrm{cfu} / \mathrm{ml}$ total hydrocarbon utilizers (THCU); nitrate, $15.60 \mathrm{mg} / \mathrm{l}$; phosphate, $3.63 \mathrm{mg} / \mathrm{l}$; sulphate, $3.0 \mathrm{mg} / \mathrm{l} ; \mathrm{pH}, \quad 7.6$, dissolved oxygen (DO) $2.10 \pm 0.02 \mathrm{mg} / \mathrm{l}$ and biochemical oxygen demand (BOD), $240.01 \pm 2.01 \mathrm{mg} / \mathrm{l}$ ), while the control set-ups (CSUA, CSUB and CSUC) were inoculated with $200 \mathrm{ml}, 250 \mathrm{ml}$ and $300 \mathrm{ml}$ sterile distilled water respectively for comparison of results. The progress of bioremediation of the experimental set-ups as well as that of the control set-ups was monitored by determining the mean changes in the total counts of heterotrophic microorganisms, hydrocarbon utilizers, and in the concentrations of residual oil, dissolved oxygen (DO) and biochemical oxygen demand
(BOD), at intervals of 2 weeks over a period of 12 weeks (Nwachukwu, 2000a).

Sample Collection: Before the set up of the experiments and controls, 3 random samples each of kitchen effluent $(20 \mathrm{ml}$ each) and drilling muds $(10 \mathrm{~g}$ each) were collected. The samples from each sampling point were combined and mixed thoroughly before analysis. Immediately after the set up of the experiments and controls, 3 random samples $(10 \mathrm{~g}$ each) were collected from both the experiments and the controls. The samples from each point were also combined and mixed thoroughly before analysis. Other samples analyzed were collected from each experiment and control at 2 weeks intervals for a period of 12 weeks.

Chemical Analysis: The $\mathrm{pH}$ of the liquid sample, (kitchen effluent) was determined using portable $\mathrm{pH}$ meter with combine glass and calomel electrodes. The $\mathrm{pH}$ meter was standardized with buffer solutions $\mathrm{pH}$ 4.0, 9.0 and 7.0, after which the samples were tested in turn. The $\mathrm{pH}$ of the drill cuttings samples was determined in the same manner but using a suspension of a 1:5 (Drilling muds - distilled water) ratio (APHA, 1995; Nwachukwu and Ugoji, 1995; Nwachukwu, 2000b). Phosphate, sulphate and nitrate concentrations were determined spectrophotometrically using the method of APHA (1995). The residual oil was extracted from the samples using n-hexane : dichloromethane solvent system (1:1) and quantified by gravimetric method (Yveline et al., 1997). To achieve this, $5 \mathrm{~g}$ of homogenized drilling mud sample was weighed into a $75 \mathrm{ml}$ beaker and $50 \mathrm{ml} \mathrm{n}$-hexane : dichloromethane was added to extract the residual oil in the sample. After shaking vigorously, the mixture was allowed to stand for about 5 minutes and then filtered through whatman No 1 filter paper into a $75 \mathrm{ml}$ beaker of known weight $\left(\mathrm{W}_{1}\right)$ as residual oil extract (ROE). The residual oil extract was placed in an oven at $80^{\circ} \mathrm{C}$ for 5-10 minutes to evaporate the solvent system (Nwachukwu, 2000b). The combined weight of the residual oil and the beaker was taken and recorded as $\mathrm{W}_{2}$. The residual oil content (ROC) was then obtained by difference in mass $\left(\mathrm{W}_{2}-\mathrm{W}_{1}=\mathrm{ROC}\right)$ (Yveline et al., 1997; Nwachukwu, 2000b; Okolo et al., 2005). The dissolved oxygen (DO) was determined using Orion portable DO meter after dilution with oxygenated water. For biochemical oxygen demand (BOD) determination, the initial DO of the oxygenated samples was determined and repeated after 5 days incubation period using Winkler method (Odiete, 1999; Singh et al., 1999; Nwachukwu, 2000a). Then, BOD was calculated as outlined by APHA (1980). The difference between 
dissolved oxygen at day zero and that at the fifth day multiply by a dilution factor gives the $\mathrm{BOD}_{5}{ }^{20}$.

Microbiological Analysis: Heterotrophic microbial counts were determined by plating serially diluted samples on nutrient agar (for bacteria) and on potato dextrose agar (for fungi). Oil-degrading microorganisms were enumerated on minimal salt agar using crude petroleum as carbon and energy source as previously reported ( Nwachukwu, 2000a).

Statistical Analysis: The data obtained for the samples from the experiments and controls were fitted to t-test statistic for significance evaluation (Esan and Okafor, 1995; Gupta, 1981).

\section{RESULTS AND DISCUSSION}

The initial drop in total heterotrophic microorganisms (THM) of the experimental set-ups (Tables 1, 3 and 5) confirms the toxic impacts of the hydrocarbon products present in the drilling muds which is in accordance with the previous reports by Atlas (1981), Nwachukwu and Ugoji (1995), and Nwachukwu (2000b), and probably prove that some of the microorganisms introduced into the experimental setups from the kitchen effluent can not survive in an oil polluted environment (Nwachukwu, 2000b), compared to the control set-ups (Tables 1, 3 and 5) which do not show any initial decrease in THM. Microorganisms require inorganic nutrient sources (mineral elements) for growth (Andrew and Jackson, 1996), however, If any of the required inorganic nutrients is lacking or becomes limiting particularly those needed in relatively large amounts known as macro mineral elements such as $\mathrm{P}, \mathrm{S}, \mathrm{C}, \mathrm{N}_{2}$, the oil pollutant degraders will not grow even though other factors such as carbon and energy required for growth are available (Nwachukwu et al., 2000).
Therefore, the introductions of kitchen effluent which contain higher content of $\mathrm{P}, \mathrm{S}$, and $\mathrm{N}_{2}$ into the experimental set-ups would have probably increased the quantity of these elements available for the growth of the oil pollutant degraders. Table 1, 3 and 5 also show a more rapid increase in the mean population densities of hydrocarbon utilizers present in the experimental set-ups compared to the control set-ups and this could also be attributed to the addition of kitchen effluent to the experimental setups. For example, the percentage total hydrocarbon utilizers (\% THCU) calculated for both experimental set-ups and control set-ups relative to the total heterotrophic microorganisms, THM (Tables 1, 3 and $5)$ differed significantly at $5 \%$ probability level $(\mathrm{t}=$ $3.833 ; 3.844$ and 3.840 for $\mathrm{A}, \mathrm{B}$ and $\mathrm{C}$ respectively; $\mathrm{t}$ from statistical table $=2.179$ ).

The results summarized in tables 2, 4 and 6 revealed that the magnitude of loss in residual oil concentration (ROC), dissolved oxygen level (DO), and the increasing trends in biochemical oxygen demand (BOD) were much more pronounced in the experimental set-ups compared with the control setups. However, the values obtained from t-test analysis of residual oil content calculated for the experimental and control set-ups at 5\% level of significance $(\mathrm{t}=1.646 ; 1.990$; and 2.219 for $\mathrm{A}, \mathrm{B}$ and $\mathrm{C}$ respectively, $\mathrm{t}$ from statistical table $=2$. 179) shown that the differences between the mean residual oil concentration (ROC) of the experimental set-ups and that of the control set-ups for $\mathrm{A}$ and $\mathrm{B}$ are insignificant while that of experimental and control set-ups for $\mathrm{C}$ differed significantly at $5 \%$ probability level, indicating that the magnitude of loss in residual oil concentrations increases as the volume of kitchen effluent introduced into the experimental set-ups increases.

Table 1: Mean population densities of different microbial groups enumerated in experiment A and Control A

\begin{tabular}{|c|c|c|c|c|}
\hline \multirow{3}{*}{$\begin{array}{l}\text { Sampling } \\
\text { Time } \\
\text { (Weeks) }\end{array}$} & \multicolumn{4}{|c|}{ Mean Population Densities (cfu/g+ } \\
\hline & \multicolumn{2}{|c|}{ Experimental set-up A } & \multicolumn{2}{|c|}{ Control set-up A } \\
\hline & Total HM & Total HCU;\% & Total HM & Total HCU; \% \\
\hline $\mathrm{O}$ (a) & $271.7 \pm 0.2$ & $1.2 \pm 0.2 ; 0.4$ & $20.3 \pm 0.2$ & $0.1 \pm 0.0 ; 0.6$ \\
\hline (b) & $20.4 \pm 0.3$ & $0.1 \pm 0.0 ; 0.9$ & $20.4 \pm 0.3$ & $0.1 \pm 0.0 ; 0.7$ \\
\hline 2 & $25.4 \pm 0.3$ & $2.1 \pm 0.1 ; 8.4$ & $21.2 \pm 0.5$ & $0.2 \pm 0.0,0.7$ \\
\hline 4 & $33.0 \pm 0.4$ & $3.2 \pm 0.2 ; 9.8$ & $23.1 \pm 0.4$ & $0.2 \pm 0.0 ; 0.9$ \\
\hline 6 & $39.5 \pm 0.2$ & $4.8 \pm 0.3 ; 12.1$ & $25.0 \pm 0.5$ & $0.4 \pm 0.0 ; 1.4$ \\
\hline 8 & $45.1 \pm 0.5$ & $7.0 \pm 0.2 ; 15.5$ & $26.3 \pm 0.3$ & $0.7 \pm 0.2 ; 2.8$ \\
\hline 10 & $52.1 \pm 0.4$ & $9.3 \pm 0.5 ; 17.9$ & $29.8 \pm 0.5$ & $1.1 \pm 0.2 ; 3.8$ \\
\hline 12 & $61.0+0.5$ & $12.1+0.2 ; 19.9$ & $35.8+0.4$ & $1.7 \pm 0.2 ; 4.8$ \\
\hline
\end{tabular}


The Use of Kitchen Effluent.....

Table 2: Mean change in chemical parameters in experiment A and control A

\begin{tabular}{|c|c|c|c|c|c|c|}
\hline \multirow{3}{*}{$\begin{array}{l}\text { Sampling } \\
\text { Time (Weeks) }\end{array}$} & \multicolumn{5}{|c|}{ Mean Changes In Chemicals Parameters $\underline{ \pm S D}$} & \\
\hline & \multicolumn{3}{|c|}{ Experiment A } & \multicolumn{3}{|c|}{ Control A } \\
\hline & $\begin{array}{l}\text { Dissolved } \\
\text { oxygen } \\
(\mathrm{mg} / \mathrm{kg})\end{array}$ & $\begin{array}{l}\text { Biochemical } \\
\text { Oxygen demand } \\
(\mathrm{mg} / \mathrm{kg})\end{array}$ & $\begin{array}{l}\text { Residual oil } \\
\text { content } \\
(\mathrm{g} / \mathrm{kg}) \\
\end{array}$ & $\begin{array}{l}\text { Dissolved } \\
\text { oxygen } \\
(\mathrm{mg} / \mathrm{kg}) \\
\end{array}$ & $\begin{array}{l}\text { Biochemical } \\
\text { Oxygen demand } \\
(\mathrm{mg} / \mathrm{kg})\end{array}$ & $\begin{array}{l}\text { Residual } \\
\text { oil } \\
\text { content } \\
(\mathrm{g} / \mathrm{kg}) \\
\end{array}$ \\
\hline O (a) & $4.2 \pm 0.1$ & $10.0 \pm 2.1$ & $48.7 \pm 1.1$ & $4.2 \pm 0.0$ & $10.0 \pm 1.1$ & $48.7 \pm 1.2$ \\
\hline (b) & $4.2 \pm 0.0$ & $10.0 \pm 1.0$ & $49.1 \pm 1.3$ & $4.2 \pm 0.0$ & $10.0 \pm 1.0$ & $49.1 \pm 1.3$ \\
\hline 2 & $3.1 \pm 0.1$ & $32.1 \pm 3.0$ & $45.8 \pm 2.1$ & $3.7 \pm 0.0$ & $18.0 \pm 1.8$ & $46.9 \pm 2.6$ \\
\hline 4 & $3.0 \pm 0.0$ & $45.0 \pm 2.6$ & $42.0 \pm 1.1$ & $3.7 \pm 0.1$ & $15.2 \pm 3.3$ & $45.0 \pm 2.0$ \\
\hline 6 & $2.5 \pm 0.0$ & $46.1 \pm 2.6$ & $36.8 \pm 0.9$ & $3.6 \pm 0.1$ & $14.6+4.1$ & $43.0 \pm 2.0$ \\
\hline 8 & $2.3 \pm 0.0$ & $42.0 \pm 3.2$ & $31.7 \pm 1.3$ & $3.6 \pm 0.0$ & $16.3 \pm 1.1$ & $41.1 \pm 3.1$ \\
\hline 10 & $2.2 \pm 0.0$ & $40.2 \pm 1.1$ & $26.9 \pm 2.1$ & $3.8 \pm 0.0$ & $17.0 \pm 1.6$ & $39.1 \pm 1.1$ \\
\hline 12 & $2.2 \pm 0.0$ & $43.3+2.2$ & $22.7 \pm 1.1$ & $4.0 \pm 0.0$ & $16.1+2.0$ & $37.1 \pm 1.1$ \\
\hline
\end{tabular}

$\mathrm{SD}$, standard deviation; $\mathrm{a}$, after application of kitchen effluent or sterile distilled water; $\mathrm{b}$, before application of kitchen effluent or sterile distilled water.

Table 3:Mean Population densities of different microbial groups enumerated in experiment B and control B

\begin{tabular}{|c|c|c|c|c|}
\hline \multirow{4}{*}{$\begin{array}{l}\text { Sampling } \\
\text { Time } \\
\text { (Weeks) }\end{array}$} & \multicolumn{4}{|c|}{ Mean Population Densities $(\mathrm{cfu} / \mathrm{g}+\mathrm{SD}) \times 10^{4}$} \\
\hline & \multirow{2}{*}{\multicolumn{2}{|c|}{ Experiment B }} & \multirow{2}{*}{\multicolumn{2}{|c|}{ Control }} \\
\hline & & & & \\
\hline & Total HM & Total HCU;\% & Total HM & Total HCU; \% \\
\hline $\mathrm{O}$ (a) & $339.6 \pm 0.2$ & $1.5 \pm 0.2 ; 0.4$ & $20.2 \pm 0.3$ & $0.1 \pm 0.0 ; 0.6$ \\
\hline (b) & $20.5 \pm 0.2$ & $0.2 \pm 0.0 ; 0.7$ & $20.5 \pm 0.2$ & $0.2 \pm 0.0 ; 0.7$ \\
\hline 2 & $31.8 \pm 0.4$ & $2.7 \pm 0.0 ; 8.4$ & $20.9 \pm 0.0$ & $0.2 \pm 0.0 ; 0.7$ \\
\hline 4 & $41.4 \pm 0.2$ & $4.1 \pm 0.3 ; 9.8$ & $22.5 \pm 0.4$ & $0.2 \pm 0.2 ; 0.9$ \\
\hline 6 & $49.3 \pm 0.5$ & $6.0 \pm 0.2 ; 12.2$ & $24.3 \pm 0.6$ & $0.3 \pm 0.0 ; 1.4$ \\
\hline 8 & $56.4 \pm 0.3$ & $8.7 \pm 0.2 ; 15.5$ & $25.9 \pm 0.3$ & $0.7 \pm 0.2 ; 2.8$ \\
\hline 10 & $65.1 \pm 0.3$ & $11.7 \pm 0.4 ; 18.0$ & $29.0 \pm 0.5$ & $1.1 \pm 0.1 ; 3.8$ \\
\hline 12 & $76.2 \pm 0.5$ & $15.2 \pm 0.1 ; 19.9$ & $35.1 \pm 0.4$ & $1.7 \pm 0.1 ; 4.8$ \\
\hline
\end{tabular}

SD, standard deviation; $a$, after application of kitchen effluent or sterile distilled water; b, before application of kitchen effluent or sterile distilled water; $\mathrm{HCU}$, hydrocarbon utilizers; HM, heterotrophic microorganisms; cfu, colony forming units.

\begin{tabular}{|c|c|c|c|c|c|c|}
\hline \multirow{3}{*}{$\begin{array}{l}\text { Sampling } \\
\text { Time } \\
\text { (Weeks) }\end{array}$} & \multicolumn{6}{|c|}{ Mean Changes In Chemicals Parameters + SD } \\
\hline & \multicolumn{3}{|c|}{ Experiment B } & \multicolumn{3}{|c|}{ Control B } \\
\hline & $\begin{array}{l}\text { Dissolved } \\
\text { oxygen } \\
(\mathrm{mg} / \mathrm{kg})\end{array}$ & $\begin{array}{l}\text { Biochemical } \\
\text { Oxygen demand } \\
(\mathrm{mg} / \mathrm{kg})\end{array}$ & $\begin{array}{l}\text { Residual oil } \\
\text { content } \\
(\mathrm{g} / \mathrm{kg})\end{array}$ & $\begin{array}{l}\text { Dissolved } \\
\text { oxygen } \\
(\mathrm{mg} / \mathrm{kg})\end{array}$ & $\begin{array}{l}\text { Biochemical } \\
\text { Oxygen } \\
\text { demand } \\
(\mathrm{mg} / \mathrm{kg})\end{array}$ & $\begin{array}{l}\text { Residual } \\
\text { oil } \\
\text { content } \\
(\mathrm{g} / \mathrm{kg})\end{array}$ \\
\hline O (a) & $4.0 \pm 0.0$ & $10.0 \pm 2.1$ & $48.2 \pm 2.1$ & $4.0 \pm 0.0$ & $10.0 \pm 1.1$ & $48.2 \pm 2.1$ \\
\hline (b) & $4.0+0.0$ & $10.1 \pm 3.0$ & $49.0+1.1$ & $4.0 \pm 0.0$ & $10.0+2.1$ & $49.0 \pm 1.1$ \\
\hline 2 & $3.0 \pm 0.1$ & $40.1 \pm 2.1$ & $44.6 \pm 2.0$ & $3.8 \pm 0.1$ & $17.0 \pm 1.1$ & $46.4 \pm 3.0$ \\
\hline 4 & $2.9 \pm 0.0$ & $56.3 \pm 1.2$ & $39.8+1.3$ & $3.7 \pm 0.0$ & $18.2+2.2$ & $44.5 \pm 2.1$ \\
\hline 6 & $2.5 \pm 0.0$ & $57.6 \pm 2.0$ & $33.3 \pm 1.0$ & $3.6 \pm 0.0$ & $18.0 \pm 1.0$ & $42.5 \pm 1.1$ \\
\hline 8 & $2.2 \pm 0.0$ & $52.5 \pm 2.0$ & $27.0 \pm 2.5$ & $3.6 \pm 0.0$ & $17.4 \pm 1.2$ & $40.6 \pm 3.2$ \\
\hline 10 & $2.0 \pm 0.0$ & $50.3 \pm 1.3$ & $21.0+3.2$ & $3.8 \pm 0.0$ & $17.0 \pm 2.3$ & $38.6 \pm 2.1$ \\
\hline 12 & $2.0 \pm 0.0$ & $54.1 \pm 2.2$ & $15.7 \pm 3.3$ & $3.9 \pm 0.0$ & $18.0 \pm 3.0$ & $36.7 \pm 1.2$ \\
\hline
\end{tabular}

SD, standard deviation; a, after application of kitchen effluent or sterile distilled water; $b$, before application of kitchen effluent or sterile distilled water. 
The Use of Kitchen Effluent.....

Table 5: Mean Population densities of different microbial groups enumerated in experiment $\mathrm{C}$ and control C

\begin{tabular}{|c|c|c|c|c|}
\hline \multirow{3}{*}{$\begin{array}{l}\text { Sampling } \\
\text { Time } \\
\text { (Weeks) }\end{array}$} & \multicolumn{4}{|c|}{ Mean Population Densities (cfu/g士SD) x } \\
\hline & \multicolumn{2}{|r|}{ Experiment $\mathrm{C}$} & \multicolumn{2}{|l|}{ Control C } \\
\hline & Total HM & Total HCU;\% & Total HM & $\begin{array}{l}\text { Total HCU; } \\
\%\end{array}$ \\
\hline O (a) & $407.5 \pm 0.2$ & $1.8 \pm 0.0 ; 0.5$ & $20.2 \pm 0.0$ & $0.1 \pm 0.0 ; 0.7$ \\
\hline (b) & $407.5 \pm 0.2$ & $0.2 \pm 0.0 ; 0.8$ & $20.5 \pm 0.4$ & $0.2 \pm 0.0 ; 0.8$ \\
\hline 2 & $38.1 \pm 0.1$ & $3.2 \pm 0.0 ; 8.4$ & $20.8 \pm 0.0$ & $0.2 \pm 0.0 ; 0.7$ \\
\hline 4 & $49.7 \pm 0.4$ & $4.9 \pm 0.0 ; 9.8$ & $22.5 \pm 0.2$ & $0.2 \pm 0.1 ; 0.9$ \\
\hline 6 & $59.3 \pm 0.5$ & $7.2 \pm 0.2 ; 12.1$ & $24.0 \pm 0.3$ & $0.3 \pm 0.0 ; 1.4$ \\
\hline 8 & $67.6 \pm 0.0$ & $10.5 \pm 0.1 ; 15.5$ & $25.8 \pm 0.5$ & $0.7 \pm 0.0 ; 2.8$ \\
\hline 10 & $78.1 \pm 0.2$ & $14.0 \pm 0.0 ; 17.9$ & $28.8 \pm 0.3$ & $1.1 \pm 0.0 ; 3.8$ \\
\hline 12 & $91.5+0.4$ & $18.2 \pm 0.0 ; 19.9$ & $35.0 \pm 0.0$ & $1.7 \pm 0.0 ; 4.8$ \\
\hline
\end{tabular}

SD, standard deviation; a, after application of kitchen effluent or sterile distilled water; $b$, before application of kitchen effluent or sterile distilled water; HCU, hydrocarbon utilizers; HM, heterotrophic microorganisms; cfu, colony forming units.

Table 6: Mean change in chemical parameters in experiment $\mathrm{C}$ and control $\mathrm{C}$

\begin{tabular}{|c|c|c|c|c|c|c|}
\hline \multirow{4}{*}{$\begin{array}{l}\text { Sampling } \\
\text { Time (Weeks) }\end{array}$} & \multicolumn{5}{|c|}{ Mean Changes In Chemicals Parameters \pm SD } & \\
\hline & \multicolumn{2}{|c|}{ Experiment $\mathrm{C}$} & \multicolumn{4}{|c|}{ Control C } \\
\hline & Dissolved & Biochemical & Residual oil & Dissolved & Biochemical & Residual oil \\
\hline & $\begin{array}{l}\text { oxygen } \\
(\mathrm{mg} / \mathrm{kg})\end{array}$ & $\begin{array}{l}\text { Oxygen demand } \\
(\mathrm{mg} / \mathrm{kg})\end{array}$ & $\begin{array}{l}\text { content } \\
(\mathrm{g} / \mathrm{kg})\end{array}$ & $\begin{array}{l}\text { oxygen } \\
(\mathrm{mg} / \mathrm{kg})\end{array}$ & $\begin{array}{l}\text { Oxygen demand } \\
(\mathrm{mg} / \mathrm{kg})\end{array}$ & $\begin{array}{l}\text { content } \\
(\mathrm{g} / \mathrm{kg})\end{array}$ \\
\hline \multirow{2}{*}{$\begin{array}{l}\mathrm{O} \\
\text { (a) } \\
\text { (b) }\end{array}$} & $4.0+0.0$ & $10.1+2.7$ & $48.0+1.2$ & $4.0+0.0$ & $10.1+1.1$ & $47.9+1.1$ \\
\hline & $4.0+0.0$ & $10.1+3.0$ & $48.7+1.3$ & $4.0+0.0$ & $10.1+3.1$ & $48.7+1.3$ \\
\hline 2 & $2.9+0.0$ & $48.2+2.2$ & $43.6+2.2$ & $3.6+0.0$ & $18.1+2.1$ & $46.3+1.2$ \\
\hline 4 & $2.6+0.0$ & $67.5+1.3$ & $37.9+1.1$ & $3.6+0.0$ & $18.1+3.0$ & $44.2+1.0$ \\
\hline 6 & $2.2+0.0$ & $69.2+2.1$ & $30.1+3.0$ & $3.5+0.0$ & $18.0+0.1$ & $42.3+1.3$ \\
\hline 8 & $2.0+0.0$ & $63.0+1.1$ & $22.5+1.2$ & $3.5+0.0$ & $18.0+2.2$ & $40.3+2.2$ \\
\hline 10 & $1.9+0.0$ & $60.3+2.3$ & $15.3+4.0$ & $3.4+0.0$ & $18.0+1.2$ & $38.4+1.2$ \\
\hline 12 & $1.9+0.0$ & $65.0+2.2$ & $9.0+2.2$ & $3.1+0.0$ & $18.0+2.0$ & $36.4+2.2$ \\
\hline
\end{tabular}

$\mathrm{SD}$, standard deviation; $\mathrm{a}$, after application of kitchen effluent or sterile distilled water; $\mathrm{b}$, before application of kitchen effluent or sterile distilled water.

Therefore, the decrease in ROC which was much more rapid in the experimental set-ups could be attributed to the additional activities of the hydrocarbon utilizers introduced into the experimental set-ups by the addition of kitchen effluent. Also the decrease in dissolved oxygen (DO) and the increase in biochemical oxygen demand (BOD) which was much more remarkable in the experimental set-ups (Table 2, 4 and 6) were probably due to the greater oxygen consumption in breaking down the oil pollutants resulting in higher values for BOD when compared with the control setups which is in line with previous reports (Singh et al., 1999; Nwachukwu, 2000a). Thus oxygen is a necessary requirement in crude oil degradation (Atlas, 1981).

Conclusion: It was clear that immediately after the introduction of the kitchen effluent into the experimental set-ups, the environment changed due to the toxicity of the oil present in the drilling muds resulting in the death of many microorganisms present in the introduced kitchen effluent, hence the initial drop in the total heterotrophic microorganisms (THM). However, some of the microorganisms that can utilize hydrocarbons soon adapted to the oiled environment and probably utilized it as a substrate for growth, hence the reduction in the ROC. Therefore, kitchen effluent could probably be used as an alternative inoculum to enhance rehabilitation of oil contaminated drilling muds before it is discharged to avoid further pollution of human environment with oil and to also ameliorate the cost of developing a particular strains or species of a particular genus of microorganisms before introducing them into the oil polluted environment. 


\section{REFERENCES}

Amadi, A; Uebari, Y (1992). Use of poultry manure for amendment of oil polluted soils in relation to growth of maize (Zea mays L). Environ. Intern. 18: 521-527.

Andrew, RWJ; Jackson, JM (1996). Pollution and waste management. In: Environmental Science: The natural environment and human impact. Longman, Singapore Publishers (Pte) Ltd. pp. 281-297.

APHA, (1980). Standard methods for the examination of water and waste water. $15^{\text {th }}$ ed. APHA-AWWA-WPCF. Washington D.C.

APHA, (1995). Standard methods for the examination of water and waste water. $19^{\text {th }} \mathrm{ed}$. APHA-AWWA-WPCF. Washington D.C. pp. (4-85) - (4-137).

Atlas, RM (1981). Microbial degradation of petroleum hydrocarbons: An environmental perspective. Microbiol Rev. 45: 180-209.

Atlas, RM (1991). Microbial hydrocarbon degradation: Bioremediation of oil spills. J. Chem. Technol. Biotechnol. 52: 149-156.

Barton, L; Schipper, LA; Barkle, GF; McLeoa, M; Speir, TW; Taylor, MD; et al. (2005). Waste mangment, land application of domestic effluent onto four soil types, plant uptake and nutrient leaching. J. Environ. Qual. 34: 635643.

Benka-Coker, MO; Olumagin, A (1995). Waste drilling fluid-utilising microorganisms in a tropical mangrove swamp oilfield location. Bioresour. Technol. 53: 211-215.

Bond, WJ (1998). Effluent irrigation - An environmental challenge for soil science. J. Soil Res. 36: 543-555.

Candler, JE; Rushing, JH; Leuterman, AJJ (1993). Synthetic-based mud systems. SPE paper 25993, pp. 485-499. In: SPE/EPA. Exploration and Production Environmental Conference, San Antonio, Texas, USA, 7-10 March 1993.

Eriksson, M; Dalhammar, G; Borg-Karlson, AK (2000). Biological degradation of selected hydrocarbons in an old PAH/Creosote contaminated soil from a gas work site. Appl. Microbiol. Biotechnol. 53: 619-626.
Esan, EO; Okafor, RO (1995). Testing statistical hypotheses. In: Basic Statistical Methods. JAS publishers, Lagos. pp. 116-155.

Fang, CS (1990). Petroleum drilling and production operations in the Gulf of Mexico. Estuaries. 13(1): 89-97.

Gupta, CB (1981). Statistical methods. Vikas publishing house Ltd. India. pp. 200-378.

Ifeadi, CN; Nwankwo, JN; Ekaluo, AB; Orubima, II (1985). Treatment and disposal of drilling muds and cuttings in the Nigerian petroleum Industry. In: The Petroleum Industry and the Nigerian Environment. Proceedings of the 1985 Intern. Semin. pp. 55-80. Nigerian National Petroleum Corporation, Lagos (1985).

Mishira, S; Jyot, J; Kuhad, RC; Lal, B (2001). Evaluation of inoculum addition to stimulate In situ bioremediation of oily-sludgecontaminated soil. Appl. Environ. Microbiol. 67(4): 1675-1681.

Nnubia, C; Okpokwasili, GC (1993). The microbiology of drill mud cuttings from a new offshore oilfield in Nigeria. Environ. pollut. 82: 153-156.

Nwachukwu, SCU; Ugoji, EO (1995). Impacts of crude petroleum spills on microbial communities of tropical soils. Intern. J. Ecol. Environ. Sci. 21: 169-179.

Nwachukwu, SCU; James, P Gurney, TR (1999). Training of Pseudomonas aeruginosa as a polishing agent for cleaning environments polluted with hydrocarbons by step-up complex hydrocarbon utilization technique. Intern. J. Environ. Edu. Inform. 18(2): 53-66.

Nwachukwu, SCU (2000a). Enhanced rehabilitation of tropical aquatic environments polluted with crude petroleum using Candida utilis. $\mathbf{J}$. Environ. Biol. 21(3): 241-250.

Nwachukwu, SCU (2000b). The use of land for field evaluations of the impact of crude oil on the biotic and abiotic factors in developing bioremediation strategies for agricultural land upon pollution with crude petroleum or petroleum products. J. Environ. Biol. 21(4):359-366. 
The Use of Kitchen Effluent.....

Nwachuku, SCU; James, P; Gurney TR (2000). Inorganic nutrient utilization by "trained" Pseudomonas putida used in the bioremediation of agricultural soil polluted with crude petroleum. Abstract of the joint Millennium Meeting of the Int. Soc. Appl. Microbiol. and Soc. Gen. Microbiol, Warkick University, UK, pp. 14.

Nweke, CO; Okpokwasili, GC (2003). Drilling fluid base oil biodegradation potential of a soil Staphylococcus species. Afr. J. Biotechnol. 2(9): 293-295.

Odiete, WO (1999). Hydrocarbons pollution In: Environmental physiology of animals and pollution. Diversified Resources Ltd. Lagos, Nigeria, 1: 180-192.

Ogboghodo, I; Erebor, E; Osemwota, I; Isitekale, H (2004). The effects of application of poultry manure to crude oil polluted soils on maize growth and soil properties. Environ. Monitoring and Assessm. 96: 153-161.

Okolo, JC; Amadi, EN; Odu, CTI (2005). Effects of soil treatments containing poultry manure on crude oil degradation in a sandy loan soil. Appl. Ecol. Environ. Res. 3(1): 47-53.
Okpokwasili, GC; Nnubia, C. (1995). Effects of oil spill dispersants and drilling fluids on substrate specificity of marine bacteria. Waste Manag. 15(7): 515-520.

Petrazzuolo, G; Michael, AD; Menzie, CA; Plugge, $\mathrm{H}$; Zimmerman, EJ; Rolan, RG; et al. (1985). Assessment of environmental fate of effects of discharges from offshore oil and gas operation. EPA 440/4-85/002. Washington D.C. 384p.

Sayler, GS; Ripp, S (2000). Field applications of genetically engineered microorganisms for bioremediation process. Current opinion in Biotechnol. 11: 286-289.

Singh, HP; Mishra, JP; Mahaver, LP (1999). Observation on biochemical and chemical oxygen demands of certain polluted stretch of river Ganga. J. Environ. Biol. 20(2): 111-114.

Yveline, ID; Frederic, J; Pierre, D; Michael, G; Jean, CB; Gilbert, M (1997). .Hydrocarbon balance of a site which had been highly and chronically contaminated by petroleum waste of a refinery from 1956-1992. Mar. Pollut. Bull. 34(6):456-468. 